\title{
THE ROLE OF ISLAMIC EDUCATION IN DEVELOPING MULTICULTURAL ATTITUDE
}

\author{
Sri AndriAstuti \\ Institut Agama Islam Negeri (IAIN) Metro, Indonesia \\ E-mail: sriandriastuti@metrouniv.ac.id
}

\begin{abstract}
Islamic education has a major contribution in developing a mulitcultural attitude in Indonesia which has a diversity of ethnicities, nationalities, races, cultures, gender, and religion. Islamic teachings carried by Islamic education are loaded with multicultural values. Islam highly respects and values differences by instilling an attitude of sympathy, appreciation, respect and empathy. The difference is sunnatullah which must be addressed wisely and gracefully. Through understanding the differences and respecting differences can minimize the occurrence of conflicts such as disputes, divisions, and wars between tribes, nations, races, cultures, genders, and religions.
\end{abstract}

Keyword: education, Islam, multicultural, attitude.

\begin{abstract}
Abstrak
Pendidikan Islam memiliki kontribusi besar dalam mengembangkan sikap mulitcultural di Indonesia yang memiliki keragaman etnis, kebangsaan, ras, budaya, gender, dan agama. Ajaran Islam yang diusung oleh pendidikan Islam sarat dengan nilai-nilai multikultural. Islam sangat menghormati dan menghargai perbedaan dengan menanamkan sikap simpati, penghargaan, hormat dan empati. Perbedaannya adalah sunnatullah yang harus disikapi dengan bijak dan anggun. Dengan memahami perbedaan dan menghormati perbedaan dapat meminimalkan terjadinya konflik seperti perselisihan, perpecahan, dan perang antar suku, bangsa, ras, budaya, gender, dan agama.
\end{abstract}

Kata kunci: pendidikan, Islam, multikultural, sikap.

\section{A. Introduction}

Indonesian society is a pluralistic society. Indonesian society consists of various ethnic groups, languages, cultures and religions. The diversity of tribes, languages, cultures, and religions is prone to cause social conflicts if not properly anticipated. As happened in Papua, Mesuji, Wamena, Sampit, Poso, and Ambon ${ }^{1}$. This social conflict caused property losses, even dozens of lives lost. Seeing these conditions, it is necessary to develop multicultural education, Islamic education is no exception. Because the Indonesian nation is a nation with the largest number of Muslims on earth. Multiculturalism is an understanding that moves to understand and accept differences that exist in each individual. Willingness to accept other groups equally as a unit regardless of differences, ethnicity, culture, language, gender, or religion. Multiculturalism emphasizes cultural diversity in equality. Multiculturalism recognizes and glorifies differences in equality both individually and culturally ${ }^{2}$. The concept of multiculturalism needs to be transformed in the form of multicultural education.

\footnotetext{
${ }^{1}$ https://www.boombastis.com . https://www.kompas.com

${ }^{2}$ Tri AstutikHaryati, Islam dan Pendidikan Multikulturalisme, Tadrîs. Volume 4. Nomor 2. 2009, h. 156
} 
Through multicultural education, social conflicts can be minimized. With multicultural education, the community is given awareness of diversity (plurality), equality, humanity, justice, and democratic values in a variety of social life activities ${ }^{3}$.

The concept of multicultural education is relevant to the Indonesian motto "Unity in Diversity", which is different but still one. Although the Indonesian people consist of various ethnicities, races, cultures, languages and religions, they remain in the unity of the Republic of Indonesia.In the national education system law number 20 of 2003 article 4 paragraph 1 regarding the principle of the implementation of education stated that "education is carried out in a democratic and fair and not discriminatory by upholding human rights, religious values, cultural values, and national pluralism"4. This shows that multicultural education is relevant to the principles of education in Indonesia.

Multicultural education can be implemented in all educational institutions, both formal and non-formal. Even multicultural education can be implemented in informal education. Islamic education as one of the educational institutions in Indonesia also has a contribution in the implementation of multicultural education in Indonesia. Through the learning process students are equipped and implanted about knowledge to live in the midst of society, given an understanding and awareness of diversity, equality, humanity, justice, and democratic values.

To develop a life orientation towards humanity, togetherness, and peace in the midst of a pluralistic society requires a positive social attitude. A positive social attitude is indicated by the willingness to recognize, accept and value diversity. Acceptance, recognition and appreciation of diversity are social attitudes that are needed in building harmonious social relations in a pluralistic society. Multicultural education has a strong interest in developing positive social attitudes. Cultural education rejects social attitudes that tend to be racial, stereotyped, and prejudiced against people or other groups of different ethnicity, race, language, culture, and religion.

\section{B. Multicultural Education and Its Characteristics}

The existence of multicultural education cannot be separated from the events of the civil rights movement that occurred in the 1960s in America. This movement emerged against the background of discriminatory life practices, both in public places, in homes, in the workplaces, and in educational institutions, carried out by the majority against minority groups ${ }^{5}$.

The practice of discriminatory life occurs because in the 1950s in America only knew the dominant and majority culture, namely white culture. In addition, the white population is classified as a minority with the limitation of their rights. Though factually America is inhabited by a population of diverse origins. The American population can be grouped into two groups, namely Native Americans

\footnotetext{
${ }^{3}$ Ali Murtadho, Menngembangkan Pendidikan Multikultural dalam Pembelajaran PAI, AlTadzkiyyah: Jurnal Pendidikan Islam, Volumen 7, Mei 2016, h. 2

${ }^{4}$ Undang-Undang Sisdiknas (Sistem Pendidikan Nasional) nomor 20 Tahun 2003, (Jakarta, SinarGrafika, 2003), h. 6

${ }^{5}$ Abdullah Aly, Pendidikan Islam Multikultural di Pesantren: TelaahterhadapPesantren Modern Islam Assalaam Surakarta, h. 88
} 
and migrants. The migrants come from various countries such as Italy, Africa, Germany, Poland and Spain. These discriminatory practices have drawn protests from minority groups, especially from black African-Americans.

In addition to social factors, another factor driving the emergence of multicultural education is the factor of educational discrimination. Educational institutions in America in the 1960s and 1970s did not provide equal opportunities for all races to obtain education. The practice of education in America in the two decades and in previous years was very discriminatory, especially against black school-aged children and children with disabilities. The practice of discriminatory education is reinforced by a discriminatory curriculum and learning approach as well'.

The practice of discrimination in education has also drawn protests from leaders of the civil rights movement and scientific institutions. They demanded reforms in education. They demanded that everyone have the same right to education. Because education is a human right. The education curriculum and learning aspects need to be reformed because the learning process and curriculum design that has taken place so far have not paid attention to aspects of cultural diversity in society.

As an ideology, multiculturalism that arises in the midst of the dynamics that develop in western societies leads to segregation and the neglect of individual and group rights has contributed to the birth of the multicultural movement in which multicultural education also exists. There are at least three important things in multiculturalism, namely (1) relating to culture, (2) referring to the diversity that exists, and (3) regarding specific actions on the response to religion ${ }^{7}$.

The subsequent echo of multicultural education not only in America, but spread to various countries such as countries in Europe, Australia and even in Indonesia. Discourse about multicultural education continued to roll until the 20th century. Multicultural education discourse in Indonesia since 2000. Study of multicultural education in Indonesia through symposium studies, discussions, seminarn workshops, and scientific discourse through newspapers, journals, and books 8 .

There are several terms used in multicultural education, namely interethnic education, transcultural education, multiethnic education, cross-cultural education9. These terms mean the provision of equal opportunities to students who have different ethnic and cultural backgrounds to obtain education. Meanwhile UNESCO gave a new term for multicultural education, namely inclusive education10. Inclusive education implies giving students the opportunity to obtain education regardless of their physical, intellectual, social, emotional, linguistic, and other conditions.

${ }^{6} I b i d$, h. 91

${ }^{7}$ ZainalArifin, Pendidikan Islam Multikultural Upaya Menumbuhkan Kesadaran Multikultural, Al-Insyirah Volume 2, Nomor 2, 2018, h. 39

${ }^{8}$ Abdullah Aly, Pendidikan Islam Multikultural di Pesantren: Telaa hterhada pPesantren Modern Islam Assalaam Surakarta, (Yogyakarta, PustakaPelajar, 2011), h. 101

${ }^{9}$ Ibid, h. 103

${ }^{10}$ UNESCO, "Inclusive Education" dalamhttp://portal-unesco.org/education/en/ev.phpURL_ID $=12078 \&$ URL_DO=DO_PRINTPA 
Etymologically, the term multicultural education consists of two syllables, namely education and multicultural. Education has the meaning of the process of changing attitudes and behavior of a person or group of people in an effort to mature humans through teaching and training efforts ${ }^{11}$. The multicultural is rooted in the word multi which means plural and cultural means culture or culture. So multiculturalism is cultural diversity ${ }^{12}$. Thus etymologically multicultural education is an educational process that pays attention to cultural diversity.

In terminology multicultural education is the concept of education that provides equal opportunities to all students regardless of gender and social class, ethnicity, race, religion, and their cultural characteristics for learning in the classroom13. This definition is built on the principles of democracy, equality and justice. This definition illustrates that to get an education is the right of all people regardless of their cultural background. They have the same opportunity to get the same education and treatment from educational institutions.

Another opinion states that multicultural education is education that helps students develop the ability to recognize, accept, appreciate, and celebrate cultural diversity14. This definition is built based on social attitudes, namely recognition, acceptance, and appreciation. This definition emphasizes the importance of respecting and respecting human dignity and dignity even though different ethnic, racial, cultural and religious backgrounds will create a harmonious, safe, and comfortable life.

Multicultural education has 3 (three) characteristics, namely (1) multicultural education is principled in democracy, equality, and justice; (2) multicultural education oriented to humanity, togetherness and peace; and (3) multicultural education develops an attitude of acknowledging, accepting, and appreciating cultural diversity ${ }^{15}$.

The principles of democracy, equality, and justice underline that all children have the same right to education. This principle is in line with the UNESCO program on education for all, which is an education program that provides equal opportunities for all children to obtain education. Not only the same opportunity in getting an education, even every child has the right to get the same treatment to get teaching in the classroom. Multicultural education ensures that children get the same attention regardless of their skin color, ethnicity, language, culture and religion. Cultural education also does not distinguish between smart and stupid children and diligent and stupid children. With the same treatment, children will get opportunities to achieve scientific competence and skills according to their interests.

To develop the principles of democracy, equality and justice, a universal life orientation is needed. Universal life orientation is humanity, togetherness, and peace. Humanity is a value that places increased human development, existence, and dignity as the highest human thoughts and actions. While

${ }^{11}$ Tatang S, Ilmu Pendidikan, (Bandung: PustakaSetia, 2012), h. 13

${ }^{12}$ RonggoWarsito, Pendidikan Multikultural, JurnalTribakti, Volume 21, Nomor 1, Januari 2010

${ }^{13}$ Abdullah Aly, Pendidikan Islam Multikultural di Pesantren: Telaah terhadap Pesantren Modern Islam Assalaam Surakarta, h. 106

${ }^{14}$ Ibid, h. 108

${ }^{15}$ Ibid, h. 109 
togetherness is one's attitude towards others, or one's attitude towards groups and communities. In togetherness there is a unity of feelings and attitudes among different individuals in the group, whether the group is in the form of family, community, ethnicity, or social class. Togetherness is the value that underlies the relationship between someone with someone else, or someone with a group and community.

As for peace is the ideal of all people who live in the midst of a heterogeneous society. The peace of life in a society can be realized by avoiding violence, war, and acts of selfishness, and by bringing justice. Multicultural education is tasked to shape students' mindset of the importance of building a harmonious social life without hostility, conflict, violence, and selfishness.

To develop a life orientation towards humanity, togetherness, and peace in the midst of a pluralistic society requires a positive social attitude, namely the willingness to recognize, accept, and respect diversity. An attitude of accepting, acknowledging, and appreciating diversity is needed in a pluralistic social life. Acceptance, recognition and appreciation of diversity are social attitudes that are needed in building harmonious social relations in a pluralistic society. Multicultural education has a strong interest in developing positive social attitudes. Multicultural education rejects social attitudes that tend to be racial, stereotyped, and prejudiced against people or other groups of different ethnicity, race, language, culture, and religion.

The three universal life orientations are the orientation points for cultural education. Thus cultural education opposes the existence of life practices that tarnish the values of humanity, togetherness, and peace such as violence, hostility, conflict, and individualism.

\section{The Role of Islamic Education in Developing Multicultural Attitudes}

Islamic education is a process of transformation and internalization of the values of Islamic teachings that originate from the Qur'an and Hadith. In the learning process, students are taught and instilled the values of Islamic teachings. Islam is a religion rahmatan lil'aalamin. Islam is a universal religion, for all humanity16. In Islam, universal values about humanity, equal rights, recognition of cultural diversity, and pluralism are upheld. In Al-Qur'an the letter Al Hujurat verse 13 states:

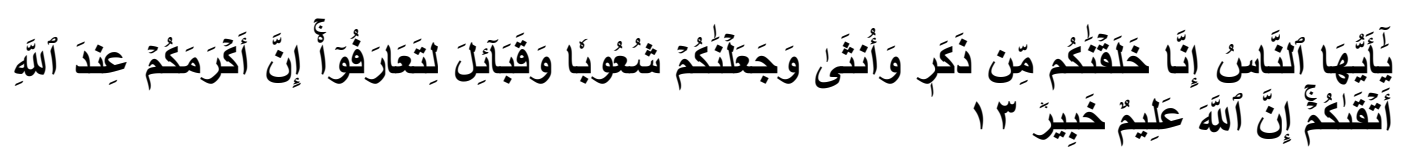

It means: "O people, Verily We created you from a man and a woman and made you nationals and tribes so that you might know one another. Indeed, the most noble among you by Allah is the most pious among you. Surely Allah knows best, knows all the more ". (Surat al-Hujurat: 13)

In a hadith it is stated that:

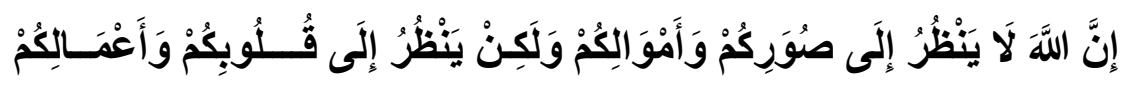

${ }^{16}$ Nurcholish Madjid, Islam Doktrindan Peradaban, (Jakarta: Yayasan Wakaf Paramadina, 1995), h. 178 
It means: "Indeed, Allah does not see your appearance and wealth, but rather see your heart and charity" (HR. Muslim No. 2564).

The above verse and hadith explain that multiculturalism is sunnatullah.Pluralism is a "divine decision" and sunnatullah ${ }^{17}$. Humans were created by various nations, tribes, skin colors, cultures, and religions to get to know and respect each other. Therefore everyone will face the fact of diversity wherever he lives and in any case. Islamic teachings emphasize that individual differences should not be used as an excuse to divide.Existing differences must be united in order to build a social order consisting of differences. Precisely with these differences should move to compete to produce the best work.

In the history of Islamic Civilization also known the "Medina Charter". All residents of Medina must abide by the Medina Charter. In the Medina Charter it is stated that among the residents of Medina must help one another, Muslims and Jews provide mutual security funds, Muslims and Jews are free to carry out religious activities without disturbing each other, each group maintains honesty and loyalty in a shared life, if there is a dispute and dispute, the problem will be reported to the Prophet Muhammad and he will give a fair decision18.

Through the Medina Charter, Rasulullah SAW. succeeded in uniting different religious groups and traditions in Medina and its surroundings. The people of Medina, despite the diversity of religions and traditions, obtained their rights and freedoms to carry out religious traditions and practices without disturbing one another. They lived life in harmony, peace, mutual respect, helping one another and maintaining the security of Medina.

Islam teaches respecting religious differences. With the concept of lakuum diinakum waliyadiin, Islam teaches that between believers do not interfere with each other and respect each other. Each adherent of a different religion is given the right and freedom to carry out religious obligations in accordance with their respective religions.

Thus multicultural values have been deeply rooted in Islamic teachings. Islam exists in the midst of society to teach living together mutual respect among diverse members of the community. In the life of multicultural society, life becomes very dynamic because there is cooperation as well as healthy and open competition from each element to do the best towards progress and benefit together.

In Islamic Education, these cultural values are embedded in the learning process. For example by teaching QS. Al Hujurat verse 13, students are introduced to differences in ethnicity, nationality, race, culture, and religion. Students are taught to stay away from negative prejudices and instill positive prejudices against ethnic, national, racial, cultural and religious differences. Students are taught to respect differences by instilling an attitude of sympathy, appreciation, respect and empathy for different tribes, nations, races, cultures and religions. Through understanding the differences and respecting differences can minimize the occurrence of conflicts such as disputes, divisions, and wars between tribes, nations, races, cultures, genders, and religions.

\footnotetext{
${ }^{17} \mathrm{Ibid}$, h 160

${ }^{18}$ Hasan Ibrahim Hasan, SejarahdanKebudayaan Islam Jilid 1, (Jakarta: KalamMulia, 2001), h. 188
} 
Thus Islamic education is actually education that is culturally oriented. According to the concept of Islamic teachings, educators teach and give understanding to students to appreciate differences. Students are taught to be able to accept differences as sunnatullah which must be accepted with grace and wisdom. So even though different ethnic, nationality, race, culture, gender, and religion are instilled for mutual understanding and mutual respect.

\section{Conclussion}

Multicultural education is an educational process that pays attention to cultural diversity and helps students develop the ability to recognize, accept, appreciate, and celebrate cultural diversity. The characteristics of multicultural education, which is based on the principles of democracy, equality, and justice oriented towards humanity, togetherness, and peace; and develop an attitude of acknowledging, accepting, and appreciating cultural diversity. Islamic education which is rooted in the values of Islamic teachings is loaded with cultural values. Islamic education carries universal values about humanity, equal rights, recognition of cultural diversity, and pluralism upheld. Islamic education teaches students to be able to accept differences as sunnatullah which must be accepted with grace and wisdom

\section{Bibliography}

Abdullah Aly, Pendidikan Islam Multikultural di Pesantren: Telaah terhadap Pesantren Modern Islam Assalaam Surakarta, Yogyakarta, PustakaPelajar, 2011

Ali Murtadho, MenngembangkanPendidikanMultikulturaldalamPembelajaran PAI, AlTadzkiyyah: JurnalPendidikan Islam, Volumen 7, Mei 2016

Hasan Ibrahim Hasan, SejarahdanKebudayaan Islam Jilid 1, Jakarta: KalamMulia, 2001

https://www.boombastis.com . https://www.kompas.com

Nurcholish Madjid, Islam Doktrin dan Peradaban, Jakarta: Yayasan Wakaf Paramadina, 1995

Ronggo Warsito, Pendidikan Multikultural, Jurna lTribakti, Volume 21, Nomor 1, Januari 2010

Tatang S, Ilmu Pendidikan, Bandung: Pustaka Setia, 2012

Tri AstutikHaryati, Islam dan Pendidika nMultikulturalisme, Tadrîs. Volume 4. Nomor 2. 2009

Undang-Undang Sisdiknas (Sistem Pendidikan Nasional) nomor 20 Tahun 2003, Jakarta, Sinar Grafika, 2003

UNESCO, “Inclusive Education” dalam http://portal-unesco.org/U

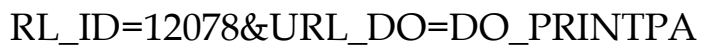

ZainalArifin, Pendidikan Islam Multikultural Upaya Menumbuhkan Kesadaran Multikultural, Al-Insyirah Volume 2, Nomor 2, 2018 